\title{
THE EFFECT OF OWNERSHIP STRUCTURE, PROFITABILITY, AND FIRM SIZE ON CORPORATE SOCIAL RESPONSIBILITY DISCLOSURE
}

\section{PENGARUH STRUKTUR KEPEMILIKAN, PROFITABILITAS DAN UKURAN PERUSAHAAN TERHADAP PENGUNGKAPAN CORPORATE SOCIAL RESPONSIBILITY}

\author{
Dea Yovita Purnomo, Ari Prasetyo \\ Departemen Ekonomi Syariah - Fakultas Ekonomi dan Bisnis - Universitas Airlangga \\ dea.yovita.purnomo-2016@feb.unair.ac.id*, ari.prasetyo@feb.unair.ac.id
}

\begin{abstract}
ABSTRAK
Penelitian ini bertujuan untuk menguji pengaruh Struktur Kepemilikan, Profitabilitas dan Ukuran Perusahaan terhadap Corporate Social Responsibility. Teknik analisis yang dipilih merupakan analisis regresi data panel menggunakan Eviews 9, pada 13 perusahaan yang terdaftar dalam Jakarta Islamic Index (JII) tahun 2015-2019 sebagai sampel dengan kriteria tertentu. Variabel struktur kepemilikan dibagi menjadi kepemilikan domestik dan asing yang diukur dengan presentase kepemilikan saham di perusahaan, profitabilitas dihitung dengan ROA, ukuran perusahaan diukur dengan ln (logaritma natural) total aset dan pengungkapan CSR dihitung menggunakan ISR dengan cara presentase pengungkapan perusahaan dibagi dengan jumlah maksimum pengungkapan tanggung jawab sosial. Hasil olah data menemukan secara statistik kepemilikan domestik memiliki hubungan negatif signifikan terhadap pengungkapan CSR. Ukuran perusahaan secara statistik memiliki hubungan positif signifikan terhadap pengungkapan CSR. Sebaliknya profitabilitas dan kepemilikan asing secara statistik memiliki hubungan positif tidak signifikan terhadap pengungkapan CSR. Secara simultan, hasil olah data menunjukkan bahwa struktur kepemilikan yang dibagi menjadi kepemilikan domestik dan asing, profitabilitas dan ukuran perusahaan berpengaruh terhadap pengungkapan CSR pada 13 perusahaan yang terdaftar di JII tahun 2015-2019.

Kata Kunci: Pengungkapan Corporate Social Responsibility, Ukuran Perusahaan, Islamic Social Reporting, Kepemilikan Asing, Kepemilikan Domestik, Pofitabilitas, Struktur Kepemilikan.
\end{abstract}

\section{ABSTRACT}

The purpose of this study is to examine the effect of ownership structure, profitability, and firm size on corporate social responsibility. The analysis technique chosen is panel data regression analysis using Eviews 9, on 13 companies listed in the Jakarta Islamic Index (JII) 2015-2019 as samples with certain criteria. The variable of ownership structure divided into domestic and foreign ownership calculated using percentage of share ownership in the company, profitability is calculated by ROA, company size is calculated using In (natural logarithm) total assets and CSR disclosure is calculated using ISR index by percentage of company disclosures divided by the number of social responsibility disclosures. The results of data processing found that statistically domestic ownership has a significant negative relationship to CSR disclosure. Firm size has a statistically significant positive relationship to CSR disclosure. On the other hand, profitability and foreign ownership have a statistically insignificant positive towards CSR disclosure. Simultaneously, the results show the ownership structure divided by domestic and foreign ownership, profitability and company size affects the CSR disclosure in 13 companies listed in JII 20152019.

Keywords: Corporate Social Responsibility Disclosure, Islamic Social Reporting, Ownership Structure, Domestik Ownership, Foreign Ownership, Profitability, Company Size.
Informasi artikel

Diterima: 07-12-2020

Direview: 19-02-2021

Diterbitkan: 25-03-2021

${ }^{*}$ Korespondensi (Correspondence): Dea Yovita Purnomo

Open access under Creative Commons Attribution-Non Commercial-Share A like 4.0 International Licence (CC-BY-NC-SA) 


\section{PENDAHULUAN}

Awalnya pengungkapan Corporate Social Responsibility (CSR) di Indonesia merupakan hal sukarela yang dilakukan oleh perusahaan. Akan tetapi pada tahun 2007 Pemerintah mengeluarkan UU No. 40 Tahun 2007 mengenai Perseroan Terbatas yang berisi kewajiban bagi perusahaan yang bergerak di bidang sumber daya untuk melaksanakan tanggung jawab sosial. Kemudian peraturan tersebut ditekankan kembali pada POJK No.51/POJK.03/2017 mengenai kewajiban seluruh perusahaan untuk mengungkapkan tanggung jawab sosial. Definisi dari tanggung jawab sosial perusahaan merupakan kewajiban berkelanjutan untuk mematuhi etika bisnis dan berpartisipasi dalam pembangunan ekonomi dan masyarakat serta menjaga lingkungan hidup. CSR muncul sebagai bentuk pertanggungjawaban terhadap lingkungan dan masyarakat dalam bentuk kegiatan sosial yang dilakukan oleh perusahaan. CSR juga termasuk elemen yang esensial dalam penilaian Good Corporate Governance (GCG).

Konsep CSR dalam ekonomi konvensional mengacu pada triple bottom line (profit, people, dan planet). Hubungan pertanggungjawaban bersifat horizontal antar masyarakat, finansial, dan lingkungan. Sedangkan dalam ekonomi syariah pertanggung jawaban sosial perusahaan tidak hanya secara horizontal (antar makhluk hidup) akan tetapi juga secara vertikal kepada Allah SWT sebagai penguasa alam semesta.

Saat ini sebagian besar perusahaan termasuk perusahaan syariah menggunakan Global Reporting Index (GRI) dan Corporate Social Responsibility Disclosure Index (CSRDI) sebagai standar pengukuran CSR mereka. Padahal AAOFI (Accounting and Auditing of Islamic Financial Institutions) menetapkan kriteria pengukuran syariah yang bernama Islamic Social Reporting (ISR). Penggunaan pengukuran konvensional disayangkan karena terdapat item-item yang tidak relevan dan tidak termasuk dalam hitungan yang sesuai dengan prinsip Islam seperti zakat, infaq dan laporan nilai tambah perusahaan. Hal ini dapat mengganggu penilaian para pembuat keputusan muslim dan berdampak buruk pada kebutuhan spiritual mereka (Haniffa and Hudaib, 2002).

Islamic Social Reporting (ISR) pertama kali diperkenalkan pada penelitian Prof. Rozaini Haniffa (2002) yang berjudul "Social Reporting Disclosure An Islamic Perspective". Selanjutnya dikembangkan oleh Othman et al., (2009) dengan menambahkan tema tema corporate governance. Oleh karena itu, terdapat enam tema/topik pengungkapan yaitu, topik pembiayaan dan investasi, topik produk, topik karyawan, topik masyarakat, topik lingkungan dan topik corporate governance.

Dalam pengungkapan CSR terdapat beberapa variabel yang mempengaruhi, salah satunya adalah struktur kepemilikan. Suto and Takehara (2012) menemukan bahwa struktur kepemilikan asing memiliki hubungan positif dan komperhensif terhadap kinerja sosial daripada kepemilikan domestik. Hal tersebut sesuai dengan Hart dan Moore (1990); Finkelstein (1992) yang berasumsi bahwa kepemilikan memiliki pengaruh terhadap perancangan keputusan organisasi, motivasi, dan kekuasaan. Pemilik perusahaan memiliki pengaruh dalam memutuskan kebijakan dan strategi yang hendak diambil demi tercapainya visi dan misi perusahaan tak terkecuali, dalam kegiatan CSR.

Blowfield \& Murray (2008); Heal (2005) berpendapat bahwa CSR merupakan dampak kinerja perusahaan terhadap manusia dan lingkungan dengan menjaga profit agar perusahaan tetap berjalan. CSR digunakan untuk meningkatkan citra perusahaan (Henderson, 2010); berkontribusi terhadap diferensiasi produk di pasar ekspor dan meningkatkan kinerja ekspor (Boehe dan Cruz, 2010); meningkatkan daya saing industri manufaktur (Flammer, 2013) serta dapat meningkatkan pertumbuhan pendapatan dan kepuasan pelanggan (Lev et al., 2010). Semakin tinggi profitabilitas akan menyebabkan semakin besar operasional perusahaan sehingga, dapat berpengaruh terhadap lingkungan dan masyarakat sekitar. Akibatnya perusahaan akan meningkatkan tanggungjawab sosial mereka.

Perusahaan tidak hanya menguntungkan, tetapi juga berdampak pada aktivitas sosial perusahaan. Perusahaan besar cenderung memiliki profitabilitas yang lebih tinggi dibandingkan perusahaan kecil. Perusahaan besar cenderung mendapatkan tuntutan untuk melakukan pengungkapan informasi secara lengkap dan komprehensif kepada stakeholder, baik informasi keuangan maupun informasi tanggung jawab sosial (Irmadariyani et al., 2019).

Berdasarkan latar belakang di atas, peneliti tertarik menggunakan indeks ISR untuk menganalisis struktur kepemilikan, profitabilitas, dan ukuran perusahaan yang diungkapkan oleh CSR. Penelitian ini diharapkan dapat digunakan sebagai kajian tentang penetapan standar evaluasi pengungkapan tanggungjawab sosial syariah, yang berjudul "Pengaruh Struktur Kepemilikan, 
Profitabilitas, dan Ukuran Perusahaan terhadap Pengungkapan Corporate Social Responsibility”.

\section{LANDASAN TEORI DAN PENGEMBANGAN HIPOTESIS Stakeholder Theory}

Menurut definisi Freeman (1999) stakeholder adalah sekelompok atau individu yang dapat memberikan dampak atau terdampak dari tujuan organisasi. Stakeholder yang dimaksud merupakan pelanggan, pemasok, karyawan, masyarakat, dan masyarakat umum, selain manajer, pemegang saham, dan kreditor (Prado-Lorenzo, 2009). Dapat disimpulkan bahwa stakeholder merupakan seluruh segmen yang memiliki keterikatan langsung atau tidak langsung dengan perusahaan.

Foster dan Jonker (2005), Hawkins (2006), Jamali (2008) (dalam Prado-Lorenzo, 2009) teori pemangku kepentingan/ stakeholder meyakini kebutuhan shareloder dapat terpenuhi apabila telah memenuhi kebutuhan stakeholder. Kepentingan untuk mendapatkan laba sebanyak-banyaknya dan penciptaan nilai bagi pemegang saham bukan merupakan satu-satunya tujuan manajemen. Melainkan, manajemen perlu untuk menjalin hubungan yang baik dengan stakeholder berlandaskan kepercayaan, kerjasama, dan rasa hormat. Salah satu tuntutan dan kebutuhan tersebut antara lain yang terkait dengan perilaku sosial dan lingkungan yang berkelanjutan.

\section{Teori Agensi}

Jansen (1976) agensi teori atau teori keagenan menjelaskan bahwa terdapat pertentangan kepentingan antara manajer dan pemegang saham, sehingga timbul konflik antar keduanya (agency problem). Perbedaan kepentingan tersebut dapat diminimalisasi dengan adanya pengawasan yang dapat menyeimbangkan kepentingan keduanya. Akan tetapi, pengawasan tersebut memunculkan biaya agensi (agency cost).

Menurut teori agensi, CSR dapat menjadi jalan keluar dalam permasalahan keagenan dan dapat menyelaraskan berbagai kepentingan serta mengurangi asimetri informasi hingga mereduksi agency cost (Cheng, et al., 2011 dalam (Liu et al., 2016). CSR dapat digunakan untuk mengurangi biaya agensi dengan cara, memberikan renumerasi berupa reward apabila manajer melakukan pekerjaan yang baik serta memberikan pelatihan untuk menunjang skill manajer yang dapat berdampak positif antara perusahaan dengan manajer. Hal tersebut termasuk salah satu kegiatan CSR perusahaan dalam tema karyawan.

\section{Corporate Social Responsibility (CSR)}

CSR mengacu pada ide bahwa perusahaan dapat menyatukan permasalahaan sosial dan lingkungan dalam elemen bisnis mereka serta dalam interaksi dengan stakeholder secara tulus (Erope Commission, 2001). Terdapat perbedaan CSR yang dilakukan oleh ekonomi konvensional dan ekonomi Islam. Ekonomi konvensional lebih menekankan kepada tanggungjawab secara horizontal. Tanggung jawab sosial tersebut menggunakan triple bottom lines (TBL) yang meliputi profit, social (masyarakat) dan planet (lingkungan). Dalam ekonomi Islam tanggung jawab sosial dilakukan secara horizontal dan vertikal. Tanggung jawab horizontal memiliki kesamaan dengan konvensional akan tetapi, tanggung jawab vertikal bermakna bahwa perusahaan memiliki hubungan tanggung jawab secara langsung kepada Allah SWT untuk berpartisipasi dalam kesejahteraan sosial dan menjaga lingkungan (Akbar, 2017).

\section{Islamic Social Reporting (ISR)}

Minimnya pengungkapan CSR berbasis syariah memicu munculnya standar pengukuran tanggung jawab sosial syariah yang bernama ISR (Islamic Social Reporting) (Haniffa, 2002). Indeks ISR berisi mengenai kompilasi faktor pengungkapan dalam CSR yang dibuat oleh AAOIFI (Accounting and Auditing Organization for Islamic Financial Institutions) dan kemudian dikembangkan oleh peneliti selanjutnya. Awalnya ada lima tema pengungkapan ISR (Rohana Othman and Thani, 2010) menambahkan tema corporate governance. Dengan demikian, terdapat enam topik disclosure dalam indeks ISR yaitu, topik pembiayaan dan investasi, topik produk/jasa, topik karyawan, topik masyarakat, topik lingkungan, dan topik corporate governance. Dalam setiap topik akan terdapat sub-topik disclosure yang digunakan untuk menentukan skala ISR indeks. Dalam beberapa penelitian sebelumnya terdapat perbedaan dalam sub-tema yang digunakan, hal tersebut dipengaruhi oleh objek penelitian yang digunakan (Nohong, 2019). 


\section{Struktur Kepemilikan}

Dalam Islam konsep kepemilikan (ownership) menjelaskan bahwa seluruh alam semesta dan seisinya merupakan milik Allah SWT sedangkan manusia hanya sebagai wakil Allah seperti yang tersirat dalam QS. Al Fathir (35): 39. Struktur kepemilikan menggambarkan komitmen pemilik untuk menyelamatkan perusahaan (Nur'aeni, 2005). Wahyudi \& Pawesti (2006) beberapa peneliti berpendapat bahwa struktur kepemilikan dapat mempengaruhi operasional perusahaan dan pada akhirnya mempengaruhi kinerja perusahaan dalam mencapai tujuan perusahaan (yaitu memaksimalkan nilai perusahaan). Struktur kepemilikan terbagi menjadi kepemilikan domestik dan asing.

Kepemilikan domestik merupakan kepemilikan saham perusahaan yang dimiliki oleh pemodal perorangan, badan hukum dan pemerintah dalam negeri. Investor domestik memiliki hubungan yang erat dengan emiten dan dianggap memiliki informasi privat. Informasi ini akan mendorong masyarakat untuk melakukan perilaku asimetris informasi, yaitu adverse transaction (pihak-pihak yang terlibat dalam transaksi perusahaan memiliki manfaat informasi, dan pihak lain tidak dapat memperoleh informasi yang sama).

Menurut Sriayu dan Mimba (2013) definisi kepemilikan asing merupakan presentase kepemilikan saham yang dimiliki oleh investor perorangan dan badan hukum asing (Cahyani and Suryaningsih, 2016). Menurut Cahyani and Suryaningsih (2016) perusahaan asing memiliki sistem informasi yang lebih efisien yang dapat memenuhi kebutuhan internal perusahaan induk dan perusahaan asing tampaknya lebih memenuhi kebutuhan pelanggan, pemasok dan publik yang lebih besar.

\section{Profitabilitas}

Harahap (2015) mendefinisikan profitabilitas adalah kemampuan perusahaan memperoleh keuntungan dari semu fungsi dan sumber yang tersedia seperti: aktivitas penjualan, kas, modal, jumlah karyawan, jumlah cabang, dan bagian. Tingkatan profitabilitas memiliki peran yang esensial bagi manajer, pemilik perusahaan dan investor. Investor sebelum melakukan investasi akan melihat profitabilitas calon perusahaan yang akan ditanamkan modalnya. Sedangkan, manajer dan pemilik perusahaan harus menunjukkan tingkat profitabilitas yang diraih perusahaan kepada para investor sebagai kewajiban perusahaan.

\section{Ukuran Perusahaan}

Definisi ukuran perusahaan (firm size) adalah identifikasi tingkat besar kecilnya perusahaan. Firm size dapat diukur berdasarkan size equity, nilai perusahaan, serta total asset (Bambang Riyanto 2001). Perusahaan besar memiliki sumber pendanaan yang beragam serta kegiatan operasional yang tinggi. Dengan demikian, dampak yang diterima oleh stakeholder akan lebih besar.

\section{Hipotesis}

$\mathrm{H}_{1}$ : Kepemilikan Domestik berpengaruh signifikan terhadap pengungkapan CSR.

$\mathrm{H}_{2}$ : Kepemilikan Asing berpengaruh signifikan terhadap pengungkapan CSR.

$\mathrm{H}_{3}$ : Profitabilitas berpengaruh signifikan terhadap pengungkapan CSR.

$\mathrm{H}_{4}$ : Ukuran Perusahaan berpengaruh signifikan terhadap pengungkapan CSR.

\section{METODE PENELITIAN}

\section{Pendekatan Penelitian}

Pendekatan dalam penelitian ini menggunakan pendekatan kuantitatif dan teknik analisis yang digunakan merupakan regresi data panel.

\section{Model Empiris}

Berdasarkan hipotesis yang telah disusun, model empiris untuk penelitian ini digambarkan seperti pada gambar 1 di bawah ini.

\section{Jenis Data, Populasi, dan Sampel}

Jenis data dalam penelitian ini berupa data skunder yang dikumpulkan dari annual report perusahaan yang terdaftar pada Jakarta Islamic Index (JII) tahun 2015-2019. Populasinya merupakan seluruh perusahaan yang terdaftar pada JII tahun 2015-2019 dan penentuan sampel menggunakan teknik purposive sampling dengan kriteria di bawah ini: 


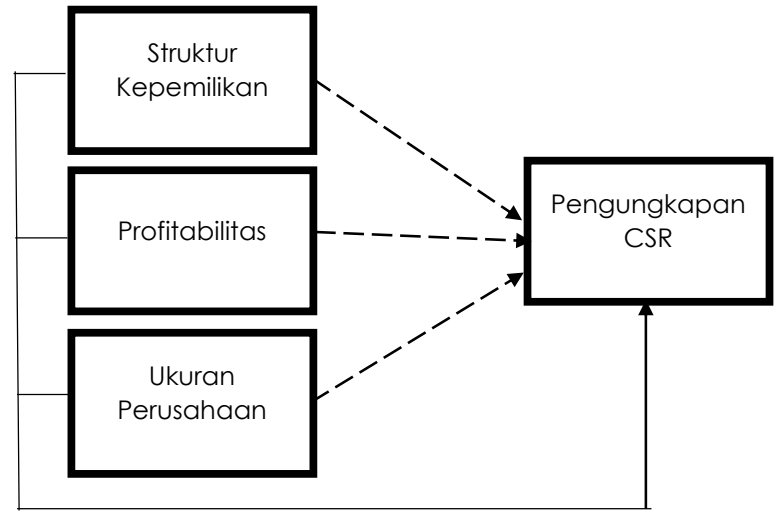

Sumber: Data diolah. 2020.

Gambar 1.

Model Empiris

Tabel 1.

Kriteria Sampel

\begin{tabular}{|c|c|c|}
\hline No. & Ketentuan Sampel & Jumlah \\
\hline 1. & Seluruh emiten yang terdaftar di JII periode 2015-2019 & 48 \\
\hline 2. & Emiten yang keluar masuk JII periode 2015-2019 & $(35)$ \\
\hline \multicolumn{2}{|c|}{ Total Perusahaan } & 13 \\
\hline
\end{tabular}

Sumber: Data diolah. 2020.

Tabel 2.

Operasional Variabel

\begin{tabular}{|c|c|c|}
\hline No. & Variabel Dependen & Rumus \\
\hline 1. & ISR & $\frac{\text { jumlah pengungkapan }}{\text { total pengungkapan maksimum }}$ \\
\hline 2. & Kepemilikan Domestik & $\frac{\text { saham milik domestik }}{\text { total seluruh saham }}$ \\
\hline 3. & Kepemilikan Asing & $\frac{\text { saham milik asing }}{\text { total seluruh saham }}$ \\
\hline 4. & Profitabilitas & ROA \\
\hline 5. & Ukuran Perusahaan & ln \\
\hline
\end{tabular}

Sumber: Data diolah. 2020.

\section{Teknik Analisis}

Teknik analisis dalam penelitian ini menggunakan analisis regresi data panel. Hsiao (2003:7) menyatakan bahwa data panel melibatkan dua dimensi, yaitu time series $(\mathrm{T})$ dan cross section $(\mathrm{N})$. Data silang adalah data yang dihimpun dengan mengobservasi suatu objek tetapi memerlukan sub objek lain yang berkaitan dalam satu observasi. Data runtut waktu merupakan pengambilan data menggunakan analisis pola hubungan antara variabel prediktor yang diprediksi dan variabel waktu.

Widarjono (2018: 363-366) menyatakan terdapat tiga model evaluasi untuk mengestimasi model regresi data panel yaitu, Common Effect Model (CEM), Fixed Effect Model (FEM) dan Random Effect Model (REM). Dalam menentukan model estimasi terbaik dilakukan Uji Chow, Uji Hausman, dan Uji Langrang Multiplier.

\section{Model Regresi}

Model regresi untuk menilai pengaruh struktur kepemilikan, profitabilitas, dan ukuran perusahaan terhadap pengungkapan CSR adalah sebagai berikut:

$\mathrm{Y}=\beta_{0}+\beta_{1} \mathrm{X}_{1}+\beta_{2} \mathrm{X}_{2}+\beta_{3} \mathrm{X}_{3}+\beta_{4} \mathrm{X}_{4}+\mathrm{e}$

Keterangan:

i : Cross-section

$\mathrm{t} \quad$ : Time series

$\mathrm{Y} \quad$ : ISR 


$$
\begin{array}{ll}
\mathrm{X}_{1} & \text { : Kepemilikan Domestik } \\
\mathrm{X}_{2} & \text { : Kepemilikan Asing } \\
\mathrm{X}_{3} & \text { : Profitabilitas (Return On Asset) } \\
\mathrm{X}_{4} & \text { : Ukuran Perusahaan (Ln) } \\
\mathrm{e} & \text { : Koefisien Error }
\end{array}
$$

Variabel ISR memakai variabel kategori dengan penambahan skor 1 apabila terdapat pengungkapan dan skor 0 apabila tidak terdapat pengungkapan pada laporan tahunan perusahaan dibagi dengan nilai maksimum pengungkapan.

\section{HASIL DAN PEMBAHASAN PEMILIHAN MODEL ESTIMASI}

Tabel 3.

Hasil Uji Chow

\begin{tabular}{|c|c|c|}
\hline Effect Test & Prob. & Keterangan \\
\hline Cross-section F & 0.00 & $\mathrm{H}_{0}$ ditolak \\
\hline
\end{tabular}

Sumber: Data diolah. 2020. Eviews9.

Hasil dari uji chow menunjukkan probabilitas sebesar $0,00<0,05$ artinya Fixed Effect Model (FEM) dipilih sebagai model estimasi.

Tabel 4.

Hasil Uji Hausman

\begin{tabular}{|c|c|c|}
\hline Effect Test & Prob. & Keterangan \\
\hline Cross-section F & 0.00 & $\mathrm{H}_{0}$ ditolak \\
\hline
\end{tabular}

Sumber: Data diolah. 2020. Eviews9.

Setelah itu, Langkah yang diambil adalah melakukan uji hausman. Pada uji hausman nilai probabilitas sebesar $0,00<0,05$. Sehingga $\mathrm{H} 0$ ditolak, model estimasi terbaik untuk penelitian ini adalah Fix Effect Model (FEM).

\section{Hasil Regresi Data Panel}

Tabel 5.

Hasil Analisis Regresi Data Panel- Fix Effect Model (FEM)

\begin{tabular}{|c|c|c|c|c|}
\hline Variabel Independen & Koefisien & t-statistic & Prob. & Keterangan \\
\hline C & 0.77 & 3.33 & 0.00 & - \\
\hline DOM & -1.52 & -4.15 & 0.00 & $\mathrm{H}_{1}$ diterima \\
\hline ASG & 0.13 & 0.15 & 0.88 & $\mathrm{H}_{0}$ diterima \\
\hline ROA & 0.02 & 0.12 & 0.91 & $\mathrm{H}_{0}$ diterima \\
\hline LN & 0.02 & 3.25 & 0.00 & $\mathrm{H}_{1}$ diterima \\
\hline $\mathrm{R}^{2}$ & 0.89 & \multicolumn{3}{|}{} \\
Obs & 65 & & & \\
Prob > F & 0,00 & & & \\
\hline
\end{tabular}

Sumber: Data diolah. 2020. Eviews9.

Berdasarkan regresi data panel menggunakan Eviews9, secara simultan struktur kepemilikan yang dibagi menjadi kepemilikan domestik dan kepemilikan asing, profitabilitas, dan ukuran perusahaan berpengaruh terhadap pengungkapan Corporate Social Responsibility. Pada Tabel 5 hasil uji $\mathrm{F}$ sebesar 0,00 yang lebih kecil dari $\alpha=0,05$ sehingga $\mathrm{H} 0$ ditolak. Berdasarkan nilai koefisien determinasi (R2) menunjukkan nilai 0,89 atau $89 \%$ artinya, variabel independen yang digunakan dapat menjelaskan pengaruhnya terhadap pengungkapan CSR. Sedangkan $11 \%$ sisanya dijelaskan oleh variabel di luar penelitian ini.

\section{Pembahasan}

Struktur kepemilikan yang dibagi menjadi kepemilikan domestik dan kepemilikan asing. Kepemilikan domestik memiliki hubungan negatif signifikan terhadap pengungkapan CSR. Hasil ini serupa dengan penelitian Schadewitz dan Blevins (1998) dan Hossain et al., (2006) mendapatkan hasil yang terbalik antara kepemilikan dalam negeri dengan pengungkapan CSR. Investor domestik mengangap praktik CSR menggunakan biaya yang lebih tinggi dan memiliki pengaruh yang kecil terhadap kinerja keuangan (Suto and Takehara, 2012); (Tokas, 2020). Sehingga investor domestik 
cenderung tidak menjadikan CSR sebagai prioritas.

Kepemilikan asing memiliki hubungan positif tidak signifikan terhadap pengungkapan CSR. Sehingga secara statistik perubahan kepemilikan asing tidak berdampak terhadap pengungkapan CSR. Sesuai dengan penelitian Amran and Devi (2008), Said et al. (2009), dan A Amran (2008) bahwa tingginya investor asing tidak berpengaruh terhadap pengungkapan kegiatan sosial perusahaan. Kepemilikan asing mungkin merasa bahwa kegiatan sosial perusahaan kurang menguntungkan karena mengeluarkan biaya yang tidak sedikit. Investor asing cenderung mencari laba sebanyak-banyaknya dan tidak menjadikan CSR sebagai prioritas.

ROA yang merupakan indicator profitabilitas memiliki hubungan positif dan tidak signifikan terhadap pengungkapan CSR. sejalan dengan penelitian Astuti (2013), Nohong (2019), dan Irmadariyani et al., (2019) bahwa semakin besar laba yang dihasilkan perusahaan tidak akan mempengaruhi kegiatan sosial perusahaan. Hal tersebut disebabkan karena, dalam memenuhi kewajiban CSR perusahaan akan mengalami kerugian akibat penurunan laba karena biaya CSR tidak dapat dihindari atau dialihkan kepada pihak lain. Sehingga perusahaan cenderung menggunakan profitabilitas yang dimilikinya untuk mendapatkan tambahan modal dan mengembangkan bisnisnya daripada melakukan kegiatan sosial yang berakibat menurunkan laba perusahaan.

LN yang merupakan simbol ukuran perusahaan memiliki hubungan positif signifikan terhadap pengungkapan CSR. Sesuai dengan penemuan Akbar (2017), Xu (2016), Irmadariyani et al., (2019) dan Rohana Othman et al., (2009) yang menyatakan bahwa ukuran perusahaan berpengaruh positif terhadap pengungkapan CSR. Semakin besar ukuran perusahaan dapat berakibat pada kenaikan kegiatan sosial perusahaan. Teori keagenan menyatakan bahwa semakin besar perusahaan maka agency cost akan semakin besar, untuk mengurangi biaya tersebut perusahaan akan mengungkapkan informasi lebih luas (Putra et al., 2011).

\section{SIMPULAN}

Penelitian ini memiliki tujuan untuk mengetahui pengaruh struktur kepemilikan, profitabilitas, dan ukuran perusahaan terhadap pengungkapan CSR secara simultan dan parsial. Dari uji hipotesis yang dilakukan dapat disimpulkan bahwa DOM dan LN berpengaruh signifikan terhadap pengungkapan CSR. Sebaliknya, ROA dan ASG tidak berpengaruh signifikan terhadap pengungkapan CSR. Seluruh variabel independen (struktur kepemilikan, profitabilitas, dan ukuran perusahaan) secara bersama-sama berpengaruh terhadap pengungkapan CSR. Variabel independen dapat menjelaskan pengaruhnya sebesar $89 \%$ terhadap variabel dependen (pengungkapan CSR).

\section{Keterbatasan}

Batasan dari penelitian ini adalah obyek penelitian yang digunakan hanya perusahaan syariah yang terdaftar di JII tahun 2015-2019, diharapkan obyek penelitian yang berbeda dapat digunakan dalam penelitian selanjutnya, misalnya perusahaan syariah yang terdaftar pada ISSI. Selanjutnya disarankan menggunakan multiple coder untuk menghindari subjektifitas dalam menginterpretasi itemitem ISR dan menambahkan variabel independen di luar struktur kepemilikan, profitabilitas, dan ukuran perusahaan.

\section{DAFTAR PUSTAKA}

Akbar, D. (2017). Investigation of intellectual capital impact and firm size to islamic social reporting with profitability as mediation on sharia banks in Indonesia. Man in India, 97(24), 413-438.

Amran, A. (2008). The impact of government and foreign affiliate influence on corporate social reporting: The case of Malaysia. Managerial Auditing Journal, 23(4), 386-404.

Astuti, T. (2013). Pengaruh profitabilitas, likuiditas dan leverage terhadap pengungkapan islamic social reporting (Studi empiris pada perusahaan yang terdaftar di bursa efek Indonesia). Jurnal Universitas Islam Negeri Syarif Hidayatullah Jakarta, 1-20.

Cahyani, C., Suryaningsih, R. (2016). The effect of leverage, board of commissioner, foreign ownership, company age, and company size towards the disclosure of corporate social responsibility (CSR) implementation. Accounting and Finance Review, 1(1), 27-33.

Freeman, R. E. (1999). Response: Divergent stakeholder theory. Academy of Management Review, 
24(2), 233-236.

Haniffa, D. R. M., Hudaib, D. M. A. (2002). A theoretical framework for the development of the Islamic perspective of accounting. Accounting, Commerce \& Finance: The Islamic Perspective Journal, 6, 1-71.

Hossain, M., Marks, B. R., Mitra, S. (2006). Stock ownership structure and voluntary disclosure of quarterly foreign sales data of U.S. multinational corporations. The Multinational Business Review, 14(3), 71-94. https://doi.org/10.1108/1525383X200600014

Irmadariyani, R., Fadah, I., Tobing, D. S. K., Wardayati, S. M. (2019). Empirical investigation of the role of Sharia's corporate social responsibility on the relationship between firm size and profitability. International Journal of Scientific and Technology Research, 8(7), 18-22.

Liu, A. M., Irwansyah., Fakhroni, Z. (2016). Peran agency cost reduction dalam memediasi hubungan antara corporate social responsibility dengan nilai perusahaan. Jurnal Ekonomi, Manajemen dan Akuntansi, 18(2), 141-156.

Nohong, M. (2019). Islamic Social Reporting disclosure and firm value: Empirical study of firms listed in Jakarta Islamic Index. Proceedings of the International Conference on Industrial Engineering and Operations Management, 2458-2494.

Othman, Rohana., Thani, A. M., Ghani, E. K. (2009). Determinants of Islamic social reporting among top shariah-approved companies in Bursa Malaysia. Research Journal of International Studies, 12(12), 4-20.

Othman, Rohana., Thani, A. M. (2010). Islamic social reporting of listed companies in Malaysia. International Business \& Economics Research Journal (IBER), 9(4), 135-144.

Prado-Lorenzo, J. (2009). Stakeholder engagement and corporate social responsibility reporting: The ownership structure effect. Corporate Social Responsibility and Environmental Management, 16(2), 94-107.

Putra, W. E., Yuliusman., Setiawan, D. (2011). Pengaruh size, profitabilitas, leverage, kepemilikan dalam negeri dan kepemilikan asing terhadap pengungkapan tanggung jawab sosial perusahaan. Jurnal Penelitian Universitas Jambi Seri Humaniora, 13(2), 37-48.

Said, R., Zainuddin, Y. H., Haron, H. (2009). The relationship between corporate social responsibility disclosure and corporate governance characteristics in Malaysian public listed companies. Social Responsibility Journal, 5(2), 212-226.

Suto, M., Takehara, H. (2012). Stock ownership structure and corporate social performance: Evidence from Japan. Diakses dari https://studylib.net/doc/6916206/stock-ownership-structure-andcorporate-social-performance

Tokas, K. (2020). Foreign ownership and corporate social responsibility: The case of an emerging market. Global Business Review, 1-24. https://doi.org/10.1177/0972150920920444

$\mathrm{Xu}, \mathrm{B}$. (2016). Profitability, state ownership, tax reporting and corporate social responsibility: Evidence from chinese listed firms. Social Responsibility Journal, 12(1), 23-31. 